\title{
EFFECT OF CREDIT RISK AND MARKET RISK ON FINANCIAL PERFORMANCE WITH LIQUIDITY AS A MEDIATION ON LPD IN BADUNG REGENCY, INDONESIA
}

\author{
Sari A.A.P. Agung Mirah Purnama*, Suindari Ni Made, \\ Lestari Ni Luh Putu Ratna Wahyu \\ Warmadewa University, Denpasar, Indonesia \\ *E-mail: agungputumirah@gmail.com
}

\begin{abstract}
The banking sector has a very vital role in the parent national goals that are intended to improve and equalize people's standard of living and support the running of economic wheels, payment transaction operators, and monetary policy transmission tools. The purpose of this study is to obtain empirical evidence on the influence of credit risk as measured by NPL, market risk measured by NIM against financial performance measured by ROA and ROE through liquidity measured by cash ratio. Quantitative methods were used in this study. The method of determining samples using saturated sampling or census so that 112 LPD can be sampled with 336 observations. The results showed that only hypothesis 5 and hypothesis 6 were accepted. Ten other hypotheses were rejected. Simultaneous leverage indicates that $62 \%$ of financial performance $(\mathrm{ROA})$ is affected by credit risk, market risk and liquidity. The remaining $38 \%$ is affected by other variables not listed on the model. While $25 \%$ of financial performance (ROE) is affected by credit risk, market risk and liquidity. The remaining $75 \%$ is affected by other variables not listed on the model. Credit risk (NPL), market risk (NIM) and liquidity (Cash Ratio) have a greater direct or indirect influence on financial performance variables as measured by ROA than ROE. In other words, ROA variables are more suitable to be used to test the influence on banking sector companies, especially in this case LPD.
\end{abstract}

\section{KEY WORDS}

Credit risk, market risk, liquidity, ROA, ROE, LPD, mediation.

Bank is an institution that serves as a financial intermediary between parties that have funds (surplus units) with parties that require funds (deficit units) as well as institutions that serve to launch payment traffic flow (OJK, 2019). One of the parties that need to know from the bank again the better the performance of the bank, the security of the investment fund is also greater. With the ratio of financial ratios, investors can know the office of a bank. The bank in its operations can not be separated from various risks. Given the bank's role in the economy and the economic impact that will be caused in the event of a failure of the banking business, therefore, a series of analysis is needed that allows to detect problems in the banking system so that failure can be anticipated and the level of health of the bank can be maintained. Performance is an important thing that must be achieved by every company anywhere, because performance is a reflection of the company's ability to manage and allocate its resources (Pinasti and Mustikawati, 2018). Profitability is the most appropriate indicator used to measure a bank's performance. The measures of profitability used are Return on Equity (ROE) for companies in general and Return on Asset (ROA) in the banking industry. in this study ROE and ROA were used to measure financial performance to compare the best results that can be obtained between the two financial performances. The high level of profitability of a bank greatly affects the level of public confidence. Banks that have high levels of profitability reflect that the bank is performing well. Credit risk is measured by Non Performing Loan (NPL). If a bank has a high NPL, it will increase costs, both the cost of reserve productive assets and other costs, in other words the higher the NPL of a bank, then it will interfere with the performance of the bank and decrease its liquidity (Pinasti \& Mustikawati, 2018). High liquidity results in high idle cash, which is certainly not profitable for 
the company and as a result the profitability of the company will be low. Maximizing profitability can affect the company's liquidity.

\section{LITERATURE REVIEW}

Delegation of decision-making authority from principal to agent is the duty of principal interest carried out by the agent. In companies whose capital consists of shares, shareholders act as principals and Chief Executive Officers (CEOs) as agents. Shareholders hire CEOs to act in accordance with the principal's interests. The relationship or contract between agent and principal is the concept of agency theory (Anthony and Govindarajan, 1995). Conflicts of interest between agents and principals often arise as a result of the assumption that each individual is solely motivated by his or her own interests. The description of an agency relationship as a relationship between the owner of the company (principal) and the agent is about the relationship of delegation of decision-making authority to the agent (Jensen and Meckling, 1976).

Explain why the company has the urge to provide financial statement information to external parties. The company's drive to provide information is because there is an information asymmetry between the company and outsiders because the company knows more about the company and its upcoming prospects than outsiders (investors, creditors). One way to reduce asymmetry information is to give signals to outsiders, one of which is financial information that can be trusted and will reduce uncertainty about the company's future prospects.

This theory assumes that a bank's liquidity will be guaranteed if the bank has a portfolio of securities that can be immediately transferred to obtain cash or liquidity. Before the 1920s, banks considered their credit portfolios to be used as a source of liquidity because at that time securities could be said to be unknown. But after the issuance of treasury bills as an intrusion into open market operations in the 1940s, from then on there was a shift from portfolio loans to money market securities as a source of bank liquidity (Silaen and Prasetiono, 2017).

Lembaga Perkreditan Desa in Chapter 1 Article 1 of Bali Governor Regulation No. 44 of 2017 concerning Bali Provincial Regulation No. 3 of 2017 concerning Lembaga Perkreditan Desa hereinafter referred to as LPD is a financial institution owned by Pakraman Village based in Pakraman Village. In Chapter IV Article 7 Paragraph 1 of Bali Provincial Regulation No. 3 of 2017 concerning Lembaga Perkreditan Desa it is explained that LPD business field includes a) receiving / collecting funds from Krama Desa in the form of dhana sepelan and dhana sesepela, b) providing loans to Krama Villages and Villages, c) LPD can provide loans to other Village Krama provided that there is cooperation between villages, d) Cooperation between villages as referred to letter $\mathrm{c}$ is further regulated by the Governor's Regulation, e) receive loans from financial institutions maximum of $100 \%$ (one hundred percent) of the amount of capital, including reserves and retained profits, unless other restrictions in the amount of loans or support / assistance funds, f) keep excess liquidity to the designated Bank in exchange for competitive interest and adequate services.

Measuring financial performance is a formal attempt to evaluate the efficiency and effectiveness of a company in generating certain profits and cash positions. With this measurement of financial performance can be seen the prospects of growth and financial development of the company from relying on the resources owned by the company. The company is said to be successful when the company has achieved a certain performance that has been determined. Measurement of financial performance plays an important role as a means or indicator in order to improve the company's operational activities.

Credit risk is the risk of the loan not returning in accordance with the contract, such as delays, reductions in interest rate payments or principal loans or not paying the loan at all. Credit risk arises due to the adverse choices and moral hazards of the loan. It is high-risk borrowers who are most willing to borrow because they expect high returns, and to get them they make adverse choices. 
Market risk is a proxy of market risk, among others, interest rates, as measured by the difference between the interest rate of funding (funding) and the interest rate given (lending) or in absolute form is the difference between the total cost of interest on funds and tota interest costs on loans where the banking term is called Net Interest Margin (NIM). There are 12 hypotheses in this study, including $\mathrm{H}_{1}$ : Credit Risk has a significant negative effect on liquidity, $\mathrm{H}_{2}$ : Market Risk has a significant positive effect on liquidity, $\mathrm{H}_{3}$ : Credit Risk has a significant negative effect on financial performance as measured by $\mathrm{ROA}, \mathrm{H}_{4}$ : Market Risk has a significant negative effect on financial performance as measured by $\mathrm{ROA}, \mathrm{H}_{5}$ : Credit Risk has a significant negative effect on financial performance as measured by ROE , $\mathrm{H}_{6}$ : Market Risk has a significant positive effect on financial performance as measured by $\mathrm{ROE}, \mathrm{H}_{7}$ : Liquidity has a significant negative effect on financial performance as measured by $\mathrm{ROA}, \mathrm{H}_{8}$ : Liquidity has a significant positive effect on financial performance as measured by $\mathrm{ROE}, \mathrm{H}_{9}$ : Liquidity mediates the effect of credit risk on financial performance as measured by $\mathrm{ROA}, \mathrm{H}_{10}$ : Liquidity mediates the influence of market risk on financial performance as measured by $\mathrm{ROA}, \mathrm{H}_{11}$ : Liquidity mediates the effect of credit risk on financial performance as measured by $\mathrm{ROE}, \mathrm{H}_{12}$ : Liquidity mediates the effect of market risk on financial performance as measured by ROE

\section{METHODS OF RESEARCH}

This type of research is a type of descriptive research with quantitative approach. This study aims to determine the influence of credit risk and market risk on financial performance with liquidity as a medianer at the Village Credit Institute in Badung Regency in 2017 - 2019. The data used is secondary data. This research was conducted in LPD Se-Kabupaten Badung, Bali. This location was chosen because Badung Regency is one of the regencies in Bali with the majority of people working in the field of tourism. Thus Badung Regency is often referred to as the largest contributor of apbd in Bali. Badung Village Credit Institute is used as a research object because lpd Badung regency development is relatively fast and as a rural economic entity is very necessary to be maintained and developed for the economic progress of village communities in the province of Bali (Budiasa, Purbawangsa and Rahyuda, 2016). It is interesting to examine whether the success of Badung Regency as the largest contributor of APBD in Bali is comparable to the financial performance of its LPD. The population of this study is LPD located in Badung Regency, Bali as much as 122 LPD.

Table 1 - Population of LPD in Badung Regency

\begin{tabular}{|c|c|c|}
\hline No. & Kecamatan & Jumlah LPD \\
\hline 1. & Abiansemal & 34 \\
\hline 2. & Kuta & 6 \\
\hline 3. & Kuta Selatan & 9 \\
\hline 4. & Kuta Utara & 38 \\
\hline 5. & Mengwi & 27 \\
\hline 6 & Petang & 122 \\
\hline
\end{tabular}

Source: LPLPD Badung Regency, 2020.

The selected non probability sampling technique is saturated sampling. Another term of saturated sampling is census, where sampling is all population of LPD In Badung Regency as much as 122 LPD. However, at the time of data collection, it was found that 10 LPD did not report its financial statements periodically. So that the final sample used only 112 LPD Se-Kabupaten Badung. Financial performance in this study was measured using Return on Assetss (ROA) and Return on Equity (ROE). Independent variables in this study were credit risk and market risk. Credit risk is measured using Non Performing Loan Ratio (NPL) and market risk is measured using Net Interest Margin Ratio (NIM). The intervening variable in this study was liquidity. Liquidity is measured using cash ratio. The analysis in this study used parametric statistics using Path Analysis which is the development of multiple linear 
regression analysis. Mediation hypothesis testing can be done with a procedure developed by Sobel (1982) and known as sobel test. One of the conditions in the use of this multiple linear regression is the fulfillment of the classic assumption test. The classic assumption test consists of (1) normality test, (2) multicolinearity test, (3) autocorrelation test, and (4) heterokedastisity test and hypothesis test consisting of (1) coefficient determination test and (2) t statistical test.

\section{RESULTS AND DISCUSSION}

Based on Table 2, it can be seen that the average credit risk measured by NPL in LPD in Badung Regency is $16.51 \%$ with a maximum value of $99.96 \%$ and a minimum value of $0.11 \%$. Market risk variables measured by NIM show an average value of $6.51 \%$ with a maximum value of $21.08 \%$ and a minimum value of $-1.56 \%$. Intervening variables as measured by liquidity, namely cash ratio, show an average value of 33.98 with a maximum value of 138.02 and a minimum value of 1.27. Financial performance variables measured by ROE show an average value of $14.12 \%$. The maximum value indicated by the ROE variable is $35.27 \%$ with a minimum value of $-47 \%$. While other financial performance variables namely ROA shows an average value of $2.86 \%$ with a maximum value of $9.75 \%$ and a minimum value of $-2.17 \%$.

Table 2 - Descriptive Statistics of Sample Company Research Variables

\begin{tabular}{|c|c|c|c|c|c|}
\hline $\mathrm{n} / \mathrm{n}$ & $\mathrm{NPL}$ & $\mathrm{NIM}$ & LIKUIDITAS & $\mathrm{ROE}$ & $\mathrm{ROA}$ \\
\hline Mean & 16,5127 & 6,5136 & 33,9847 & 14,1209 & 2,8553 \\
\hline Max & 99,96 & 21,08 & 138,02 & 35,27 & 9,75 \\
\hline Min & 0,11 & $-1,56$ & 1,27 & $-47,00$ & $-2,17$ \\
\hline Std. Dev. & 16,75847 & 2,91572 & 20,47929 & 6,45379 & 1,39398 \\
\hline Obs. & 336 & 336 & 336 & 336 & 336 \\
\hline
\end{tabular}

The results of the normality test of the effect of credit risk (NPL) and market risk (NIM) on financial performance (ROA) After being outlier and using transform data into Natural Logarithm (Ln) showed the value of Kolmogorov Smirnov $Z$ at 0,049 with asymp value. Sig. (2-tailed) of 0,051. The effect of credit risk (NPL) and market risk (NIM) on financial performance (ROE) showed kolmogorov Smirnov Z's value of 0,040 with asymp value. Sig. (2-tailed) of 0,200 . the effect of liquidity (cash ratio) on financial performance (ROE) after outliers and using transform data into Natural Logarithm (Ln) shows the value of Kolmogorov Smirnov Z of 0,047 with the value of Asymp. Sig. (2-tailed) at 0.081. Effect of liquidity (cash ratio) on financial performance (ROA) after outlier and using transform data into SQRT $(k-x) . k$ is the highest value on the liquidity variable while $x$ is the liquidity variable itself. This transform data is used because the histogram chart shows moderate negative skewness so that kolmogorov Smirnov Z value is 0.047 with Asymp value. Sig. (2-tailed) at 0,081 . These values are greater than the significance value of $5 \%$ or 0.05 so residual data is normally distributed.

The results of the multicolinearity test of the effect of credit risk (NPL) and market risk (NIM) on financial performance (ROA and ROE) showed a VIF value of 1,083 each. liquidity (cash ratio) on financial performance (ROA and ROE) shows a VIF value of 1,000 . The VIF value indicated on the variable is less than 10 . Therefore, it is concluded that there is no multicolinearity.

The results of the autocorrelation test on the influence of credit risk (NPL) and market risk (NIM) on financial performance (ROA) showed that durbin watson's value was 1,828 with a dL value of $=1,75$ and $\mathrm{du}=1,79(1,79<1,828<4$-du $(2,21)$. The effect of credit risk (NPL) and market risk (NIM) on financial performance (ROE) shows that durbin watson's value was 1,968 with $\mathrm{dL}$ value $=1,75$ and $\mathrm{du}=1,79(1.79<1,968<4-\mathrm{du}(2,21)$. The effect of liquidity (cash ratio) on financial performance (ROE) after outlier and data transformation shows that durbin watson value of 2,043 with dL value = 1,76 and du = 1,78 $(1,78<2,043<4$-du $(2,22)$. The effect of liquidity (cash ratio) on financial performance (ROA) after outlier and data 
transformation shows that watson durbin value of 1,813 with $\mathrm{dL}$ value $=1,76$ and $\mathrm{du}=1,78$ $(1,78<1,813<4$-du $(2,22)$. Thus $d$ statistics are in the area of no autocorrelation or regression model made does not contain symptoms of autocorrelation, so it is worth using to predict.

Heteroskedastisitas test results of the influence of credit risk (NPL) and market risk (NIM) on financial performance (ROA) respectively showed significance values of 0,981 and 0,111 . The effect of credit risk (NPL) and market risk (NIM) on financial performance (ROE) respectively showed significance values of 0,796 and 0,232 . the effect of liquidity (cash ratio) on financial performance (ROA) shows a significance value of 0,651 . The effect of liquidity (cash ratio) on financial performance (ROE) shows a significance value of 0,865 . The significance value indicated by these variables is greater than 0,05 . Thus it can be concluded that there is no problem of heterokedastisity in the research model.

The results of the analysis showed the calculated $t$ value on credit risk measured by NPL showed a negative direction of $-0,358$ with a significance of 0,720 greater than alpha $0,05(0,720>0,05)$ so that it was declared insignificant. This means that credit risk has no effect on liquidity so $\mathrm{H}_{1}$ is rejected.

The results of the analysis showed the calculated t value on market risk as measured by NIM showed a negative direction of $-1,064$ with a significance of 0.288 greater than alpha $0,05(0,288>0,05)$ so that it was declared insignificant. This means that market risk has no effect on liquidity so $\mathrm{H}_{2}$ is rejected.

The results of the analysis showed the calculated t value on credit risk measured by NPL showed a negative direction of $-1,447$ with a significance of 0,149 greater than alpha $0,05(0,149>0,05)$ so that it was declared insignificant. This means that credit risk has no effect on financial performance as measured by ROA so $\mathrm{H}_{3}$ is rejected. The insignificance of NPL's influence on liquidity is likely due to the discovery of uncertainty of decline and increase in NPL in 2017 to 2019. This inconsistency was also followed by an increase and decrease in $\mathrm{ROA}$ values, resulting in insignificant analysis results:

- Fourth Hypothesis Test: Analysis of the Effect of Market Risk on Financial Performance as measured by ROA.

The results of the analysis showed the calculated t value on market risk as measured by NIM showed a positive direction of 21,886 with a significance of 0,000 smaller than alpha 0,05 $(0,000<0,05)$ so that it was declared significant. This means that market risk has a significant positive effect on financial performance as measured by ROA so that $\mathrm{H}_{4}$ is rejected.

- Fifth Hypothesis Test: Analysis of the Effect of Credit Risk on Financial Performance as measured by ROE.

The results of the analysis showed the calculated $t$ value on credit risk measured by NPL showed a negative direction of $-7,061$ with a significance of 0,000 smaller than alpha $0,05(0,000<0,05)$ so it was declared significant. This means that credit risk has a significant negative effect on financial performance as measured by ROE so that $\mathrm{H}_{5}$ is accepted.

- Sixth Hypothesis Test: Analysis of The Effect of Market Risk on Financial Performance as measured by ROE.

The results of the analysis showed the calculated t value on market risk as measured by NIM showed a positive direction of 5,311 with a significance of 0,000 smaller than alpha $0,05(0,000<0,05)$ so that it was declared significant. This means that market risk has a significant positive effect on financial performance as measured by ROE so that $H_{6}$ is accepted.

- Seventh Hypothesis Test: Analysis of The Effect of Liquidity on Financial Performance as measured by ROA.

The results of the analysis showed the calculated $t$ value in liquidity as measured by the cash ratio showed a positive direction of 4,164 with a significance of 0,000 smaller than alpha $0,05(0,000<0,05)$ so that it was declared significant. This means that liquidity has a significant positive effect on financial performance as measured by $R O A$ so that $\mathrm{H}_{7}$ is rejected.

- Eighth Hypothesis Test: Analysis of The Effect of Liquidity on Financial Performance as measured by ROE. 
The results of the analysis showed the calculated $t$ value in liquidity as measured by the cash ratio showed a negative direction of $-0,036$ with a significance of 0,971 greater than alpha $0,05(0,971<0,05)$ so that it was declared insignificant. This means that liquidity has no effect on financial performance as measured by $\mathrm{ROE}$ so $\mathrm{H}_{8}$ is rejected.

- Ninth and Tenth Hypothesis Test: Analysis of the Effect of Credit Risk and Market

Risk on Financial Performance as measured by ROA with Liquidity as Intervening Variables.

The significant or not effect of credit risk on financial performance (ROA) through liquidity is evidenced by the Sobel Test as follows. Calculate the default error of the indirect effect coefficient:

$$
\mathrm{S}_{\mathrm{ab}}=\sqrt{b^{2} s a^{2}+a^{2} s b^{2}+s a^{2} s b^{2}}
$$

$\mathrm{t}$ value statistical influence mediation (intervening):

$$
\mathrm{t}=\frac{a b}{S_{a b}}
$$

Sobel test calculation result obtained t calculated value of 0,28 less than table $t$ value with signification rate of 0,05 which is 1,96 . It can then be concluded that the intervening coefficient means that liquidity variables are unable to mediate the relationship between credit risk as measured by NPL to financial performance as measured by ROA. This means the ninth hypothesis $\left(\mathrm{H}_{9}\right)$ is rejected. Sobel test calculation result obtained $t$ calculated value of $-1,06$ less than table $t$ value with signification rate of 0,05 which is 1,96 . It can then be concluded that the intervening coefficient is insignificant which means that liquidity variables are unable to mediate the relationship between market risk as measured by NIM to financial performance as measured by ROA. This means the tenth hypothesis $\left(\mathrm{H}_{10}\right)$ was rejected.

Table 3 - Summary of The Equation of Direct and Indirect Influence of Credit Risk and Market Risk on Financial Performance as Measured by ROA with Liquidity as Intervening Variables

\begin{tabular}{|c|l|c|l|}
\hline No & \multicolumn{2}{|c|}{ Equation of Paths } & \multicolumn{1}{|c|}{ Information } \\
\hline 1. & $\begin{array}{l}Y_{1}=p y_{1} x_{1} X_{1}+p y_{1} x_{2} X_{2}+ \\
\varepsilon_{1}\end{array}$ & $\begin{array}{l}Y_{1}=-0,020 X_{1}+-0,061 X_{2} \\
\varepsilon_{1}\end{array}$ & $\begin{array}{l}\text { Effect of credit risk (NPL) and market risk (NIM) on } \\
\text { liquidity }\end{array}$ \\
\hline 2. & $\begin{array}{c}Y_{2.1} \\
=p y_{2,1} x_{1} X_{1}+p y_{2.1} x_{2} X_{2} \\
+p y_{2.1} y_{1} Y_{1}+\varepsilon_{6}\end{array}$ & $\begin{array}{c}Y_{2.1}=-0,051 X_{1}+0,769 X_{2} \\
+0,140 Y_{1}+\varepsilon_{6}\end{array}$ & $\begin{array}{l}\text { Effect of credit risk (NPL) and market risk (NIM) on } \\
\text { financial performance (ROA) with liquidity as } \\
\text { intervening variables }\end{array}$ \\
\hline
\end{tabular}

The direct effect of credit risk on financial performance (ROA) was $-0,051$. Meanwhile, the indirect effect of credit risk on financial performance (ROA) through liquidity amounted to $-0,0028$. From the results of these calculations it is known that indirect influence outweighs direct influence. Thus LPD should pay attention to the cash ratio in order to save the condition of the company caused by the failure of the debtor or other parties in fulfilling their obligations to the bank. With the problem of failure in the fulfillment of obligations by the debtor, it will improve financial performance. The total direct and indirect influence of credit risk on financial performance $(\mathrm{ROA})$ through liquidity is $-0,051-0,0028=0,054$ or $-5,38 \%$.

The direct effect of market risk on financial performance (ROA) was 0,769 . While the indirect influence of market risk on financial performance (ROA) through liquidity amounted to $-0,00854$. From the results of these calculations it is known that direct influence is greater than indirect influence. Thus, any decrease in financial performance (ROA) of $5,38 \%$ is influenced by credit risk and liquidity. Thus LPD should pay attention to market risk because the market risk measured by NIM is a benchmark to know how much the bank can manage all its productive assets in order to get a higher net income. High net income will certainly also have an impact on improving financial performance. The total direct and indirect influence of market risk on financial performance $(R O A)$ through liquidity is $0,769-0,00854=$ 0,76 or $76,05 \%$. Thus, any increase in financial performance (ROA) of $76,05 \%$ is influenced 
by market risk and liquidity but the influence of market risk dominates the financial performance by $77 \%$. Simultaneous influence shows the value of $62 \%$ of financial performance $(\mathrm{ROA})$ is influenced by credit risk, market risk and liquidity. While the remaining $38 \%$ is influenced by other variables that are not listed on the model.

Sobel test calculation result obtained t calculated value of 0,35 less than table t value with signification rate of 0,05 which is 1,96 . It can then be concluded that the intervening coefficient means that liquidity variables are unable to mediate the relationship between credit risk as measured by NPL to financial performance as measured by ROE. This means the eleventh Hypothesis $\left(\mathrm{H}_{11}\right)$ is rejected. Sobel test calculation result obtained $t$ calculated value of $-1,03$ less than table t value with signification rate of 0,05 which is 1,96 . It can then be concluded that the intervening coefficient is insignificant which means that liquidity variables are unable to mediate the relationship between market risk as measured by NIM to financial performance as measured by ROE. This means the twelfth Hypothesis $\left(H_{12}\right)$ is rejected.

Table 4 - Summary of The Equation of Direct and Indirect Influence of Credit Risk and Market Risk on Financial Performance as Measured by ROE with Liquidity as Intervening Variables

\begin{tabular}{|c|c|c|c|}
\hline $\mathrm{No}$ & Equation & of Paths & Information \\
\hline & $Y_{1}=p y_{1} x_{1} X_{1}+p y_{1} x_{2} X_{2}+\varepsilon_{1}$ & $Y_{1}=-0,020 X_{1}+-0,061 X_{2}+\varepsilon_{1}$ & $\begin{array}{l}\text { Effect of credit risk (NPL) } \\
\text { and market risk (NIM) on } \\
\text { liquidity }\end{array}$ \\
\hline 2. & $\mid \begin{array}{l}Y_{2.2}= \\
p y_{2.2} y_{1} Y_{1}+\varepsilon_{7}\end{array}$ & $\begin{array}{ll}Y_{2.2}= & -0,351 X_{1}+0,264 X_{2}+ \\
-0,002 Y_{1}+\varepsilon_{7} & \end{array}$ & $\begin{array}{l}\text { Effect of credit risk (NPL) } \\
\text { and market risk (NIM) on } \\
\text { financial performance } \\
(\mathrm{ROE}) \text { with liquidity as } \\
\text { intervening variables }\end{array}$ \\
\hline
\end{tabular}

The results of the analysis showed that liquidity was unable to mediate the effect of credit risk on financial performance as measured by ROE. The direct effect of credit risk on financial performance (ROE) was $-0,351$. Meanwhile, the indirect effect of credit risk on financial performance (ROE) through liquidity amounted to 0,00004. From the results of these calculations it is known that indirect influence outweighs direct influence. The increase in non-performing loans is due to congestion in repayment. The rise in non-performing loans led to a drop in the company's profit. The total direct and indirect influence of credit risk on financial performance (ROE) through liquidity is $-0,351+0,00004=-0,35$ or $-35 \%$. Thus, any $35 \%$ decrease in financial performance $(\mathrm{ROE})$ is influenced by credit risk and liquidity.

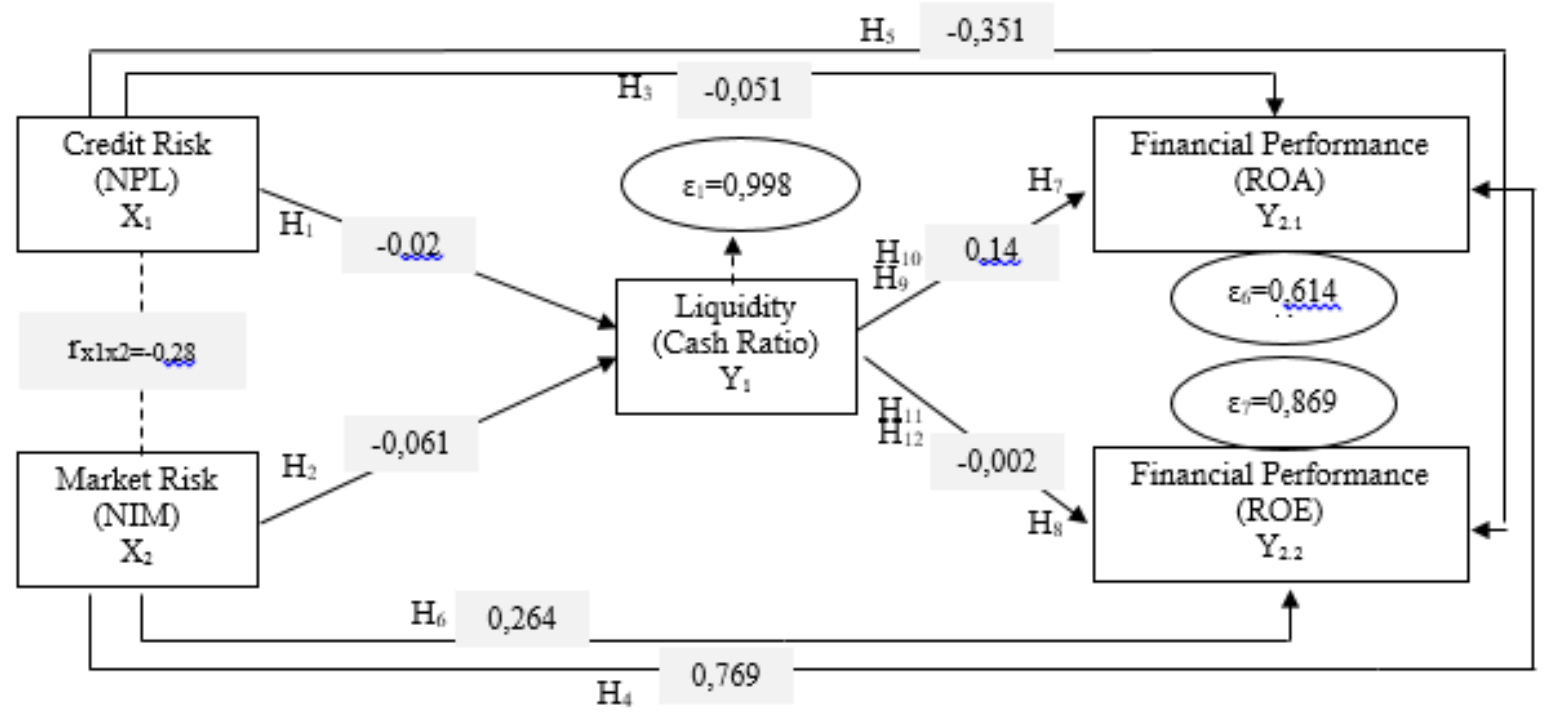

Figure 1 - Research Concept after Data Processing 
The results of the analysis test showed that liquidity was unable to mediate the influence of market risk on financial performance as measured by ROE. The direct effect of market risk on financial performance (ROE) was 0,264. Meanwhile, the indirect influence of market risk on financial performance (ROE) through liquidity amounted to 0,000122. From the results of these calculations it is known that direct influence is greater than indirect influence. NIM reflects market risks arising from the movement of market variables, which can affect bank profits. The total direct and indirect influence of market risk on financial performance (ROE) through liquidity is $0,264+0,000122=0,264$ or $26 \%$. Thus, any increase in financial performance (ROE) by $26 \%$ is influenced by market risk and liquidity but the influence of market risk dominates financial performance.

Simultaneous influence shows the value of $25 \%$ of financial performance (ROE) is influenced by credit risk, market risk and liquidity. While the remaining $75 \%$ is affected by other variables that are not listed on the model. Thus, the overall research model when combined will look like Figure 1.

\section{CONCLUSION AND SUGGESTIONS}

Based on the results and discussion in the previous chapter, it is obtained conclusions as follows: 1) Credit risk has no effect on liquidity so $\mathrm{H} 1$ is rejected, 2) Market risk has no effect on liquidity so $\mathrm{H} 2$ is rejected, 3) Credit risk has no effect on financial performance as measured by ROA so $\mathrm{H} 3$ is rejected, 4) Market risk has a significant positive effect on financial performance as measured by ROA so $\mathrm{H} 4$ is rejected, 5) Credit risk has a significant negative impact on financial performance as measured by ROE so that $\mathrm{H} 5$ is accepted, 6) Market risk has a significant positive effect on financial performance as measured by ROE so that $\mathrm{H} 6$ is accepted, 7) Liquidity has a significant positive effect on financial performance as measured by $\mathrm{ROA}$ so $\mathrm{H} 7$ is rejected, 8) Liquidity had no effect on financial performance as measured by ROE so $\mathrm{H} 8$ was rejected, 9) Liquidity is unable to mediate the relationship between credit risk as measured by NPL to financial performance as measured by ROA. This means the ninth hypothesis (H9) is rejected, 10) Liquidity is unable to mediate the relationship between market risk as measured by NIM to financial performance as measured by $\mathrm{ROA}$. This means the tenth hypothesis $(\mathrm{H} 10)$ was rejected, 11) Liquidity is unable to mediate the relationship between credit risk as measured by NPL to financial performance as measured by ROE. This means the eleventh Hypothesis (H11) is rejected, 12) Liquidity is unable to mediate the relationship between market risk as measured by NIM to financial performance as measured by ROE. This means the twelfth Hypothesis ( $\mathrm{H} 12)$ is rejected, 13) Based on the results of the analysis that is then poured into Figure 1, it can be seen that credit risk (NPL), market risk (NIM) and liquidity (Cash Ratio) have a greater direct or indirect influence on financial performance variables as measured by ROA than ROE. In other words, ROA variables are more suitable to be used to test the influence on banking sector companies, especially in this case LPD.

The results of this study provide additional empirical evidence regarding the influence of credit risk and market risk on financial performance through liquidity. Credit risk is measured by NPL, market risk is measured by NIM, and financial performance is measured by $R O E$ and ROA while liquidity is measured by cash ratio. The use of intervening variables is expected to answer the amount of direct and indirect influence of credit risk and market risk on financial performance with liquidity as an intermediary so that it is expected to reflect the true circumstances in Badung Regency LPD in 2017-2019. Some suggestions that can be given include:

LPD parties should pay attention to NPL, NIM, and Cash Ratio to increase ROA. As the results of the study that stated that $62 \%$ of financial performance (ROA) is influenced by credit risk, market risk and liquidity. In addition, NIM is proven to have a very large direct influence on ROA so it is good for LPD to pay special attention to market risks as measured by NIM. 


\section{LIMITATIONS AND RECOMMENDATIONS}

The limitations of this study lie in the time span of the study used only for three years from 2017 to 2019. The research object used is also limited to LPD Se-Kabupaten Badung so it cannot be used to generalize to other types of banking businesses or other districts in Indonesia. The financial performance variables in the study were projected with ROA and ROE. In order to increase the diversity of research, researchers are further expected to develop this study using other factors that may affect financial performance. Further researchers are also expected to further develop research objects and expand it somewhat similar research can later be naturalized throughout the banking sector. Further researchers are also expected to develop research models using other methods so that in the future similar research can develop well.

\section{REFERENCES}

1. Anthony, R. N. and Govindarajan, V. (1995) Management Control Systems. Homewood, Illinois: Irwin/ McGraw-Hil.

2. Budiasa, I. K., Purbawangsa, I. B. A. and Rahyuda, H. (2016) 'Pengaruh Risiko Usaha Dan Struktur Modal Terhadap Pertumbuhan Aset Serta Profitabilitas Pada Lembaga Perkreditan Desa Di Kabupaten Badung', E-Jurnal Akuntansi Universitas Udayana 5.7, 5(7), pp. 1919-1952.

3. Jensen, M. C. and Meckling, W. H. (1976) 'Theory Of The Firm: Managerial Behavior, Agency Costs And Ownership Structure', Journal of Financial Economics 3, 3(4), pp. $305-360$.

4. OJK (2019) Resume Peraturan Ojk Bidang Perbankan Yang Masing Berlaku Pada Tahun 2018. Available at: https://www.ojk.go.id/id/kanal/perbankan/data-dan-statistik/bookletperbankan-indonesia/Documents/Pages/Booklet-Perbankan-Indonesia-2019/Booklet Perbankan Indonesia 2019 Long Version.pdf.

5. Pinasti, W. F. and Mustikawati, R. I. (2018) 'Pengaruh Car, Bopo, Npl, Nim Dan Ldr Terhadap Profitabilitas Bank Umum Periode 2011-2015', Nominal, Barometer Riset Akuntansi dan Manajemen, 7(1). doi: 10.21831/nominal.v7i1.19365.

6. Silaen, R. and Prasetiono (2017) 'Analisis Faktor-faktor yang Mempengaruhi Tingkat Cash Holding pada Bank Umum yang Terdaftar di Bursa Efek Indonesia Tahun 20112015', Diponegoro Journal of Management, 6(3), pp. 1-11. 